\title{
Millenial Gen's Negotiation in Two Selected Pesantren Literary Works
}

\author{
Hat Pujiati \\ \{hatpujiati.sastra@unej.ac.id\} \\ English Department, Faculty of Humanities, Universitas Jember Jember, Jawa Timur, Indonesia
}

\begin{abstract}
The ruin of Matapena Community as a community for pesantren literature activist in 2014 does not end the reproduction of pesantren literature with its pesantren cultural problems as a spiritual journey in planting selfidentity in alternative medias with popular genres. This article discusses discoursive contestation of self-identity in two pesantren literary works; Sensei, Assalamualaikum Desu! by Diyana Millah Islami and Menggapai Kosong by Izzul Muttaqin. Construction of Self-identity in the literary works engages to the contestation of self-identzity discourse in the real world and the cyber world of the writers as milenial generations. Through theory of representation by Stuart Hall, I choose consructionist approach with Foucauldian discoursive model to analyze the works. Therefore, the data are taken from the two literary works and also the social phenomena relate to the years of the works have been produced to find out the meaning production constructed in works. The result shows an in-between-ess of an absoluteness of religious ideology with the open-ness of the millenial gen that limitless in time and space. Technology and latecapitalism facilitate the fluidity of time and space boundary presented in the easthetic works.
\end{abstract}

Keywords - Millenial, representation, latecapitalism, pesantren literature, technology

\section{Introduction}

In early 2000s, there were four poles of different thoughts of literary communities in Indonesia, they are Utan Kayu (now: Salihara), Forum Lingkar Pena (FLP), Matapena and the other one was those who had the same ideas of taking Indonesian literature on ASEAN's stage [1]. The last community has no spesific name since they refuse to be judged as the counters of the other previous communities. Around 2016, Matapena collapsed because of internal management in the community [2]. However Salihara and FLP are fine and their members keep publishing their works while the fourth keep moving underground [1]. The two literary communities are dominant in Indonesia and they have different school in their works. Salihara has a kind of experimental school in their works that stands under similar ideological cannopy with Jakarta Art Councils (DKJ). Zurmailis in her research shows the symbolic power of Jakarta Art Councils as doxa in Indonesian aesthetics literature [3] while FLP is under the canopy of Islamic lifestyle which tends to move people socially and culturally as a counter 
ideology of the other dominant community with sounding the subaltern to gain a concencus [4]. Matapena also uses Islamic Lifestyle in teen/chicklit genre that influence the young readers with "introduction to fiqh, Islamic hollybooks refferences, and also Pesantren jokes and terms" in it. Matapena has became the connectors of Pesantren Literature writers before its collapse. Without Matapena, those writers still survive with the Pesantren Literature.

Rahman defines Pesantren Literature as all literary works that live in Pesantren, including those works written by ones who live in Pesantren (Islamic boarding school) or even those who live outside of the pesantren (alumni) but it has themes of pesantren life [5]. Pesantren literature spreads the local wisdom of life in the Islamic boarding school that support deity and humanity [6]. Morover, in this article I would rather to take Pesantren Literature as a theme of literary works that are produced by those who live in Pesantren or those works that use pesantren themes in it than as a genre. The students' (or known as Santri for students who study in Pesantren) age are around teens to early twenties as those are the school age of the pupils. Pujiati has found in her research that Pesantren literature is also work of atrs that cannot deny its nature as a politics in telling something [7]. Furthermore, this article questions how the politics of the santri writers as millenial gens presenting their self-identity presented by Diyana Millah and Izzul Sensei, Assalamualaikum Desu! and Menggapai Kosong as my material objects. Diyana teaches Bahasa Indonesia at a senior high school in Pesantren Nurul Jadid, Paiton - Probolinggo, and Izzul is a college student in Pesantren Salafiyah Syafi'iyah, Sukorejo -Situbondo. Both of the pesantren are at the same coast, at the north beach of East Java. Both of the writers do not belong to the poles of the biggest literary communities in Indonesia, but Izzul has joined Sanggar Cermin (a literary community that grows in the salafi pesantren) in Salafiyah Syafi'iyah Sukorejo. This article asseses the two novels on the discourses relate to the contestation of self-identity produced by Santri writers as milenial generations.

\section{Method}

The Stuat Hall's Representation theory focuses on language as a centre of meaning production since language connects people to the world [8]. Concepts of things are transferred to others and also exchanged in a society through the language to make the world meaningful, that is representation. Moreover, representation is about people and culture in their society. Hall highlights three approaches deal with language-use to make the world meaningful; reflective, intentional, and contructionist approach. Hall proposes the third approach to be the ideal approach in working with representation theory. There are two models of approaching this theory in the constructionist approach, they are Saussurian and Barthesian semiotics and Foucauldian discursive models. The Semiotics model takes meaning based on the signifying structure while the Discursive model takes the analysis focus on "relation force, strategic developments and tactics". Foucault discuses more than 'meaning' but knowledge production that happen in the languange system in term he calls 'discourse'. In short, discourse is not languge "but a group of statements which provide a language for talking about at a particular time and at a particular historical moment". Furthermore, a discourse may come from many texts, sources, and actions but there is a discourse with a red line that shares sameness at certain time/moment and it regulates the that is called episteme. Many or perhaps multiples of sameness that become epistemes and then create a different discursive formation or Setiawan calls it as orbit [9]. This Foucauldian discursive model is the one I choose in analysing the literary works in this article. As this article analyzes the contestation of self-identity of santri gen $\mathrm{Y}$ and gen $\mathrm{Z}$ that are presented in the two novels, the first step that $\mathrm{I}$ do in this analysis is collecting data about self-identity construction in the novels as the primary data. They are analytical units in the form of words, sentenses and paragraphes that show self-identity 
construction. Later, the secondary data are the life of the authors as the agents of the literary works and their societies, social phenomena of Indonesian entertainment, literature, and political condition in the years of the works are produced to find out the discoursive formation of the self-identity. Finally, the genealogical construction of self-identity knowledge leads to the ideological position of the authors.

\section{Result and Discussion}

Self-identity contestation of santri as the pesantren's gen $\mathrm{Y}-\mathrm{Z}$ or that are known as millenial gen is in a negotiative position. As Santri, they are designed to be good moslems who preserve and spread God's teaching. However, as the millenial gens, they have advance sensibility on the multimedia that dismentles their consciousness upon time and space. The rigidity on the absolute ideology of religion and the open-ness of the millenial gen's sensibility are presented in their works inevitably. Technology and latecapitalism facilitate the fluidity of time and space boundary presented in the easthetic works.

\subsection{Technology and Orientation in Pesantren Literature}

One indicator of the rapid development of technology is prooved by the fast and massive production of mobile phone. Innovations rush in the gadget industry that is followed by new technology that is implanted in the newest series of gadget floods the electronic market everyday. Information is also has its huge changes in the society. It was face-to-face mode in traditional civilazation, then it moves to writing mode with printing form of exchange in modern era that also has great consequences in human civilization, and now it becomes electronic mode through electronic devices in this postmodern age [10]. However, technological backward is also a real phenomenon in this era that is twisted into various negative behaviour in the cyberspace. In Indonesia, there are some people take social media as a liberation room of value and norm since there is a failure of conciousness of the user between real and cyber. Cyberworld is a hyperreality that however cannot be juxtaposed with real life but both of them influence each other. Rude netizens spread in Indonesian social media and cyber bullying comes to real but the constitution does not support it well so that those become common. The phenomena are like deseases that is getting worse and here is the fact; literacy culture becomes weak. Hoax culture spreads and delivers post truth. The technology users are dominated by the youth and in 2017 , youthquake is legitimated as the new word in dictionary [11]. The youth who goes with the flow in this huge changes become those who has weak literacy, but those who refuse going with the flow can get a lot of advantages of this rapid development of technology.

Diyana was born in 1986 and Izzul was in 1996. The two writers belong to Y and Z generation. Mainheim devides the problems of generation into man on world war II, post ww II, boomer I generation, boomer II Generation, X generation, Y Generation (Millenial), and Z generation. Those who was born above 1980s -1997 are called as Y Generation and they are assumed as those who experience the two millenia. Furthermore, Manheim in The Problem of Generation has postulated that the generation consist of people that influence each other and they turn into similar characteristics because they experience the same sociohistorical events [12], [13]. While gen $Z$ are those who were born in 1993-1995, at a time when technology has developed. For this reason, gen $Z$ is known as the generation that is technology friendly. If Diyana is a Y generation and Izzul is $\mathrm{Z}$ generation, they are supposed to be familiar with the technology. As pesantren writers with the limitation access to technology who live in Islamic boarding school and interact with the members of the boarding schools and also the stage 
holders there, I analyses how they construct their self-identity in the stories and the technology contribution in concerning their self-identities.

\subsection{Social Media and Space of Liberation in Menggapai Kosong}

Menggapai Kosong by Izzul is about a young man named Fatih who chooses leaving his grandfather who has raised him for the sake of finding religious truth in his belief; Islam. He does a kind of pilgrimage to learn Islam from some famous priests in his journey. Love story is also a part of Fatih's journey. Before he meets his first love in the story, he meets Afkar, a young man who goes with him doing the pilgrimage. Both of the stayed in a widow's house named Kaif. They have met on street and she offers them to stay because the day is getting dark. Smart and critical discussion between Fatih and Kaif happen everyday during their stay in the house. The two young men take care Kaif's only son who lives with autism. On the day that the young men leave to continue their journey, Kaif gives a laptop to Fatih and says:

"Laptop ini untukkmu” Kaif menyodorkannya pada Fatih.

“ Kirim ke akun facebookku jika kau menemukan kisah menarik dari perjalananmu” [14].

They are falling in love but they keep it in heart. They just show that they care each other. Facebook as a social media mediated their love. In the society, loving a widow is a disgrace for a virgin. A widow has been sexually active and she is judged with her sex life by the society, so having a relationship with a virgin who is pious can be a trigger for the society to judge her as a bad woman. Menggapai Kosong crosses the border between virgin and widow, even Fatih stays in Kaif's house for few days, the story leads to critical thinking that is shown by their critical discussion [5]. There is no sexual activity between them even they have chances to do so. The love relationship between them is flourishing through facebook chatting when Fatih misses Kaif. Facebook as a social media in this story has a function like love letters in the early modern age, but using facebook is skipping points of waiting for the replay. Kaif responds the chat right away. Besides, the social media become a space of liberation for the love relationship. Menggapai Kosong tells Islamic way of life which is strict in rules for a non marital relationship of male and female. Social media here negotiates the strict rules carefully. Their love keeps on flourishing but it guarantees that there is no much physical interaction that can be a sin in Islam. The love between them is safe then.

\subsection{Promised Land and Identity}

Identity is a kind of endless distinction that is influenced by particular condition in the historical moment and also institutional, and the result is naturalized [15]. In other words, identity is a construction that relates to discursive formation. There is a scene in the story that Kaif brings his autism son to America to get a better medication. The scene shows that the Promised Land is in the United States. Kaif who is presented as a smart, rich and atheist woman represent her class in making the choice. The have can do anything and be part of the global society to save life. West is a salvation for East. When she is compared to Rabiah, a daughter of a pious priest who becomes Fatih's teacher in a pesantren where he learns Islam, Kaif is irreplaceable. Fatih makes Rabiah against her family's tradition to have an arranged marriage with a pious family too but to choose Fatih. Fatih is an ordinary young man, who was born as an illegitimate child. His mother is unmarried and such status in the society is stratified as the lowest level. Therefore, Fatih was raised by his grandfather in a rural area but he is presented as a smart young man as the compensation of his disgrace faith. His disgrace as an illegitimate son is the reason of him to do the pilgrimage, to legitimate his disgrace in the name of Islam as a belief he has been thought by his grandfather. Furthermore, Fatih's love to Rabiah ends tragically. Faith wants to show that he is independent and consistent with his carrier as a writer, and he reaches it through hard working. Rabiah leaves her comfortable life for the sake of love but this sacrificial effort is punished with a bad luck; she is raped by Afkar, she loses her mind 
because of love, and also loses her beauty [5] since she lives in the wild world, away from her big rich family. Kaif the smart and atheist ends with a conversion to Islam, Pujiati states that is a fear of diversity that is presented in the story [5]. None of the women is chosen by Fatih at the end. He is jailed because he has killed Afkar who has raped Rabiah. Fatih is conquered by his anger and gets mad in jail.

Dan sebelum genap seminggu ia melewati tempat ini.

Tuhan benar-benar rindu untuk bersamanya. Membawanya pergi pada padang abadi penghujung cerita [14].

Berita itu pun sampai ke Rabiah. Seakan mengerti dan merasakan hal yang sama, tak menangis sedikitpun Rabiah dengan meninggalnya Fatih. Wanita itu hanya tersenyum kecil, setengah berbisik, "Selamat, kau telah benar-benar sampai disana"[14].

Death is seen as an achievement in understanding deity. Fatih's death ruins all of the critical efforts in negotiating human's position in religion. God is the truth, God is fathomable but not logic, and God is the decision maker of all. What Fatih fights in his life is position in the society that is legitimized by his religion, unfortunately he has to die in jail and releasing all the desire of living in the world.

Overall, Menggapai Kosong represents violence that cannot be ignored. Rape that happen to Rabiah, the death of Fatih at the end of the story, Kaif's sick son, are punishment of questioning and negotiating the absolute truth of religion. Fatih does not come back to his village where people has bullied him as a fatherless son emphasizes that he is cursed and religion is not to be negotiated. Moreover, there is no hope in the village but the Promised Land is out there; in America, where Kaif seeks for her son's help. Meanwhile, norms and values punish ones who negotiate the absolute truth of religion here in the land.

\subsection{The Shifting Orientation in Sensei, Assalamualaikum Desu?}

The novel is about a single young teacher named Naya. She replaces her friend, Mega, at a High School in a pesantren (Islamic Boarding School). Entering pesantren makes Naya have to adapt with new rules that are sourced in the religious teaching. Naya comes from a poor family but she is lucky to finish her study at a university in town. Since her love life is also poor, she wants to leave her life as a teacher and gain a better one with studying abroad. Her love to Japanese brings her to a young man, Azaim; the crown prince of the pesantren. Naya never teaches him because there is a rule that female teachers are forbidden to teach at the male classes. Informally, some male students meet her to study the subject she teaches and also to borrow some books. The boys share their dreams of future land to visit as the following quotation;

"Kalian juga suka bahasa Jepang? Naya bertanya lagi melihat pada Yunus dan Jakfar secara bergantian.

"Suka, Bu, tapi Cuma sedikit. Kalau Yunus lebih suka bahasa Mandarin. Yunus ingin kuliah ke Cina seperti kakak-kakak angkatan yang sudah di sana. Yunus minta doanya,Bu Naya."Jelas Yunus.

Naya Mengangguk.

"Setelah kuliah nanti, Jakfar mau masuk jurusan bahasa di Korea." [16].

The title of the novel indicates Japanese's atmosphere. Such title has been preceded by Asma Nadia with Assalamualaikum, Beijing (2013). However, they are different kind. Asma Nadia tends to do syi'ar with impressing Zhongwen on Islam. Diyana Islamiyah's novel uses Asian countries as a centre of knowledge, a place to study, to gain scientific knowledge. I note this as a phenomenon that indicates the rise of Asia to Asian. There is a pride of being Asian, the construction of west as the centre of civilization is not the one and dominant. After Habiburrahman with his Ayat-Ayat Cinta pulls the west orientation into the Middle East, it is followed by many works of the same canopy writers then. Middle East is countering the west 
dominant because Middle East is known as the origins or Islam. Moreover, bringing the orientation to Asia to gain knowledge is a newness. People who study Islam intensely in a pesantren tend to highlight a verse from prophet Muhammad 'demand science to China' so that those students hunt scholarship to the Asian countries.

Diyana is a simple girl who does not interacts too much with gadget technology. Her Whatsapp in her mobile is not online everyday, and it has been installed this year. Before this year, we can only contact her through SMS or a call on her mobile phone. When the story she has written is talking about Korea, I see a correlation with K-Pop wave in Indonesia. The development of Korean entertainment industry invades us, Indonesian television has got high ratings on K-Pop performance and also K-drama. Even though Diyana is so limited in accessing internet, and not a kind of K-cheers, she interacts a lot with $\mathrm{Z}$ generation (her students) who are technologies friendly and open to K-entertainment. Therefore, Sensei, Assalamualaikum Desu! brings Korea as one of the study destination. Actually, Japanese drama comes first than the K-wave in Indonesia. In early 1990s, Indonesian national television was invaded by the J-drama, Manga, Serial Cartoons and also comics and then it was followed by the rise of Harajuku fashion trend in the world. Furthermore, J-dramas presented love stories between Japanese and Taiwanese that used email to communicate each other. The romance was mediated by the technology. Then comes the K-Wave in early 2000 s, from love drama series to K-pop and any other K-products; cultural and commercial goods. Commercial advertisements for beauty products beep in Indonesian National TV's channels for hundreds times a day and it constructs new figures of idols; K-pop/drama artist-like figures. Chinese is also has similar physical characteristics with the Koreans, they are also loveable to those K-lovers. Besides, China's products and innovations spread in the global market that proves China as a great producer, Indonesian Muslim as a majority in the society has a background knowledge on Muhammad's advice to gain science even it is to China. The knowledge legitimizes the idolism that leads to the rise of the Asia-wave among the Asian and it constructs pride of Asian. As Y generation, Diyana must have had experienced the J-wave and Sensei as the title of her novel is a trace of romanticism come from the J-dramas. Moreover, $\mathrm{K}$-wave is absorbed from the $\mathrm{Z}$ gen, a generation that is noticed as instant and techno friendly gen; a borderless generation that full of celebration. The pesantren literature mode of writing of Sensei, Assalamualaikum Densu! is framed in the science intention, but pouring the desire of freedom in the liberalism ideology overall.

\subsection{Tradition, Religion and Identity}

Pesantren where Naya teaches is a modern Islamic boarding school but however, the tradition of pesantren is still preserved well. The kyai who has a broad knowledge is placed like a king and so does his family. Pesantren is like a little kingdom. The novel questions this stratified levels between the Kyai's family and common people especially those who study in the pesantren. Reciting Koran on the grave is explained through the perspective of traditional but makes sense. There are strengthen on the traditional identity but it is combined with modern's rationality. Science is traced to its history and cling on the wise of the predecessors and the philosophy of traditional pesantren.

\section{Conclussion}

Diayana is a $\mathrm{Y}$ generation who is familiar to internet and technology that influence the modes of information. However, identity construction in the novel is not influenced by the generation closeness with technology. Intensity of social media access is repressed in pesantren and replace it with a discipline on study; ideological and scientific ones. Pesantren's walls 
become a filter and a kernel that the students or the people live in pesanten revolve in God and human relationship. It also happens in Muttaqin's novel, all the escapism finally ends with endless anxiety and death that safes as well as punishes him. However, the stories flow a double-blade plot as Millenia Gen's self-identity negotiation as an ideological position. Multitasking potency on technology because of their multimedia sensibility bring the gen $\mathrm{Y}$ and $\mathrm{Z}$ to merge and fold time and space but at the same time those writers grasp and cling on the religious doctrine as God's teaching. Therefore, they remain in in-between-ness but also accepting open-ness of the fluidity of time and space. They define themselves as religious but open and technology literate. The presentation of technology in negotiating the rigid interpretation on religious value in their daily life is politics to gain a new consensus of deity and humanity in the daily life.

\section{Reference}

[1] O. Rosmini, Discussion in channel social media. Efile, 2016.

[2] K. Rozikin, Mantan Pegiat Matamovie (bagian dari Matapena yang fokus pada film). 2017.

[3] Zurmailis and Faruk, "Doksa, Kekerasan Simbolik dan Habitus yang Ditumpangi dalam Konstruksi Kebudayaan di Dewan Kesenian Jakarta," Adab. J. Bhs. dan Sastra, vol. 1, no. 1, pp. 44-72, 2017.

[4] R. Tami, Faruk, and I. R. Adi, "Hegemonic Culture and Subaltern: A Compromised Veil in Indonesian Islamic Popular Novel," Ling. Cult., vol. 11, no. 1, 2017.

[5] H. Pujiati, "Representasi Radikalisme Dan Deradikalisme Agama Dalam Sastra Pesantren," Adab. J. Bhs. Dan Sastra, vol. 2, no. 1, 2018

[6] I. Astutiningsih and H. Pujiati, "Perspektif Santri Dalam Karya Sastra: Sebuah Representasi Wacana Religius-Humanis," Poet. J. Ilmu Sastra, vol. 7, no. 1, 2019.

[7] H. Pujiati, I. Astutiningsih, and E. Suwargono, Suara-suara Pesantren: Konstruksi Anti Radikalisme dalam Sastra Pesantren di Jember-Situbondo-Probolinggo Jawa Timur. Yogyakarta: Diandra Printing \& Offset, 2018.

[8] S. Hall, Representation: Cultural Representation and Signifying Pratices. London: SAGE Publications, 1997.

[9] I. Setiawan, "Cyber discussion on Matatimoer whatsapp group," 2018

[10] M. Poster, The Mode of Information: Poststructuralism ans Social Contenxt. Oxford: Polity Press, 1990.

[11] S. Cain, "'Youthquake' named 2017 word of the year by Oxford Dictionarie," theguardian.com, 2017. [Online]. Available: https://www.theguardian.com/books/2017/dec/15/youthquake-named2017-word-of-the-year-by-oxford-dictionaries.

[12] D. M. McCourt, "The 'Problem of Generations' Revisited: Karl Mannheim and the Sociology of Knowledge in International Relations," in Theory and Application of the "Generation" in International Relations and Politics, 2012, pp. 47-70.

[13] A. Adam, "Habis Milenial dan Generasi Z, Terbitlah Generasi Alfa," Tirto.id, 2017. .

[14] I. Muttaqin, Menggapai Kosong. Yogyakarta: Interlude, 2016.

[15] S. Hall and P. du Gay, The questions of cultural identity. London: SAGE Publications, 1996.

[16] D. M. Islamiyah, Sensei, Assalamualaiku Desu! Yogyakarta: Deepublish, 2017. 